\title{
HEALTH RELATED QUALITY OF LIFE OF CHILDREN WITH THALA SSEMIA AT TERTIARY CARE HOSPITAL IN BELAGAVI.- A CROSS SECTIONAL STUDY
}

\begin{tabular}{ll}
\hline Nursing & \\
Arer AR* & $\begin{array}{l}\text { Post Graduate, Department of Child Health Nursing, KAHER Institute of Nursing } \\
\text { Sciences, Belgaum. *Corresponding Author }\end{array}$ \\
\hline Hulagbali $\mathbf{M}$ & $\begin{array}{l}\text { Post Graduate, Department of Child Health Nursing, KAHER Institute of Nursing } \\
\text { Sciences, Belgaum. }\end{array}$ \\
\hline
\end{tabular}

\section{ABSTRACT}

A study was conducted on 90 children suffering with thalassemia who are attending thalassemia unit of KLES Dr. Prabhakar Kore Charitable Hospital Belagavi. To assess the health related quality of life of children with thalassemia and to find out the association between health related quality of life of children with Thalassemia and selected demographic variables. Purposive sampling technique was used to select the samples. Data was collected using standardized paediatric inventory quality of life (PedsQL 4.0 Generic Core Scales) tool. Data obtained was tabulated and analysed in terms of objectives of the study using descriptive and inferential statistics. The study revealed that Majority $70(77.78 \%)$ of thalassemia children had average level of quality of life where as minimum $10(11.11 \%)$ of thalassemia children had low and high level of quality of life. The association between age groups and levels of QOL is found to be not statistically significant (Chi-square $=6.3530, \mathrm{p}=0.1740$ ) and the association between religions and levels of QOL is found to be not statistically significant.

\section{KEYWORDS}

Thalassemia, Quality of life.

plant in our present to get a beautiful and fruitful garden of successful nation in the future and the quality of these saplings can define the quality of our future. We know that the childhood is the period of life that is free from stress and responsibilities. The faces of these blooming buds are almost always decorated with joy, happiness and smile but sometimes some life-long diseases can snatch the smile of these smiling faces forever. Thalassemia is one among such disorders that requires regular medical attention and frequent blood transfusions as in $\beta$-Thalassemia.

Thalassemia is hereditary disorder of blood where red blood cells are destructed due to abnormal formation of haemoglobin or inability of the body to make enough hemoglobin leading to severe anaemia. Abnormal or inadequate hemoglobin in the blood decreases its oxygen carrying capacity that leads to severe health problems and decreased body functions due to lack of proper oxygen to the cells and tissues of the body. In thalassemia there is abnormal synthesis of one or more chains of globin in the hemoglobin molecules resulting in wide variety of symptoms like anaemia, bone deformities, fatigue, delayed growth and development, hepatic splenomegaly etc. Not only physical or physiological symptoms but long term medical interventions ,medication regimens, unavoidable and frequent hospitalization can affect the psychological health, emotional stability and standard life among the children suffering from thalassemia as well as their family members or care givers, especially parents.

Thalassemia is such a disturbing and perturbing condition that affects almost all spheres of life of these children including their education, social life, self-identity and what not. These children may become extremely dependent on their parents and care givers and may consider themselves as a burden for them that can in turn lead to anxiety, depression, stress and decreased standard of life. Health Related standard of (HRQOL) of these children includes their perception of this chronic disease and its impact on their overall health status i.e. Physical, mental and social health.

\section{Need for study}

Thalassic is Greek word that means great sea, from which the Thalassemia word derived. The disease first found in patients had an origin from littoral countries of the Mediterranean Sea in the year of 1925. Now it has become very common globally. In India, prevalence of this disease is very high in Sindhi's, Gujarati's and Punjabi's. Millions of peoples are carriers of the Thalassemia gene and thousands of thalassemia children are born in our country every year.

In Indian population Beta Thalassemia is very common. Every year about $10 \%$ of Thalassemia patients belong to India in whole world thalassemia patients. Sindhi's, Gujarati's, Bengali's and Punjabi's are some Indian communities which are most commonly affected with Beta Thalassemia, the incidence may be from 1 to $17 \%$ and it showing that pathological hemoglobinopathy prevalence is about $1.2 / 1,000$ live births per year is suggesting the every year birth of 32,400 babies who have risk of serious blood disorder. A study conducted by WHO also updated that frequency of Beta Thalassemia in India is $3.45 \%$.

In the context of pediatric health research, HRQOL is considered as a vital consequence of health because children cannot express their issues and are also more susceptible in comparison to adults. HRQOOL in children is necessary in providing proper care and also helps to detect the effect of disease and its cure from children's perspective. Current studies also revealed that HRQOL of children may be utilized as an indicator of health care cost. It also aid to detect children at risk. ${ }^{6}$

As there are inadequate studies on the HRQOL of Thalassemia children, the objective of the study is to assess health related quality of children with Thalassemia in northern part of Karnataka.

\section{MATERIALAND METHODS}

A descriptive cross-sectional study was conducted on 90 children suffering with thalassemia who are attending thalassemia unit of KLES Dr. Prabhakar Kore Charitable Hospital Belagavi. Purposive sampling technique was used to select the samples from the population. Data was collected using standardized pediatric inventory quality of life (Pads 4.0 Generic Core Scales) tool. Descriptive and inferential statistics were used to analyses the data.

Pads is used in the study consists of $\mathbf{2}$ sections, Section I: consists of 6 questions seeking the demographic data of children

Section II: consist of 4 parts regarding quality of children life.

\section{RESULTS}

Major Findings of the study were:

1) Findings related to the socio-demographic variables of mothers: In the present study it was found that majority of the children with Thalassemia $47(52.22 \%)$ belonged to the age group of 11-12 yrs. Majority of the subjects $59(65.56 \%)$ were belonged to Hindu religion. Majority of the subjects $82(91.11 \%)$ belonged to joint family. Majority of the subjects $59(65.56 \%)$ were from rural place. Majority of the subjects $25(27.78 \%)$ were studying in $6^{\text {th }}$ standard.

2) Findings related to distribution of respondents according to levels of health related $Q O L$

It has been found that Out of a total of 90 respondents, in which a maximum of $70(77.78 \%)$ of respondents have average level of quality of life as compared to a minimum of only 10 (11.11) each have low and high level of QOL. The distribution of respondent by levels of QOL is 
also presented in the following figure.

Table 1: Frequency and percentage of respondents according to levels of Health related QOL

\begin{tabular}{|c|c|c|}
\hline Levels of QOL & Frequency & Percentage \% \\
\hline Low QOL $(<=$ mean-SD) & 10 & 11.11 \\
\hline Average QOL $(<$ mean-SD, $<$ meanD) & 70 & 77.78 \\
\hline High QOL $(>=$ mean+SD) & 10 & 11.11 \\
\hline Total & 90 & 100.00 \\
\hline
\end{tabular}

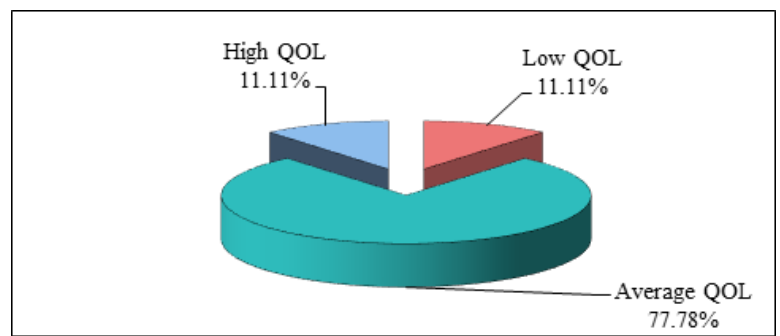

Graph 1: Pie graph showing percentage of respondents according to levels of Health related QOL

1) Findings related to association between the levels of QOL and socio demographic variables

There was no significant association was found in present study of children with thalassemia and demographic variables such as age (Chisquare $=6.3530, \mathrm{p}=0.1740)$, religion $($ Chi-square $=3.4490, \mathrm{p}=0.4860)$, nature of family (Chi-square $=0.0390, \mathrm{p}=0.9810)$, place of residence (Chi-square $=2.7560, \mathrm{p}=0.2520$ ), education of child (Chi-square $=$ $10.5620, \mathrm{p}=0.2280$ ).

\section{DISCUSSION:}

\section{Major Findings of the study were:}

In the present study it was found that majority of the children with Thalassemia $47(52.22 \%)$ belonged to the age group of 11-12 yrs. Majority of the subjects $59(65.56 \%)$ were belonged to Hindu religion. Majority of the subjects $82(91.11 \%)$ belonged to joint family. Majority of the subjects $59(65.56 \%)$ were from rural place. Majority of the subjects $25(27.78 \%)$ were studying in $6^{\text {th }}$ standard.

In the present study it was found that out of a total of 90 respondents, in which a maximum of $70(77.78 \%)$ of respondents have average level of quality of life as compared to a minimum of only 10 (11.11) each have low and high level of QOL. The distribution of respondent by levels of QOL is also presented in the following figure.

\section{CONCLUSION:}

Based on the findings of the study the following conclusions were drawn:

Out of 90 respondents, maximum $70(77.78 \%)$ respondents have average level of quality of life where as minimum 10 (11.11) respondents have low and high level of QOL.

There is no significant association was seen in present study with standard of living of children with thalassemia and demographic variables such as age $(\mathrm{Chi}$-square $=6.3530, \mathrm{p}=0.1740)$, religion $(\mathrm{Chi}-$ square $=3.4490, \mathrm{p}=0.4860)$, nature of family $($ Chi-square $=0.0390$, $\mathrm{p}=0.9810$ ), place of residence (Chi-square $=2.7560, \mathrm{p}=0.2520)$, education of child (Chi-square $=10.5620, \mathrm{p}=0.2280)$.

\section{REFERENCES}

1) S sharma, B seth, et al. Quality of Life in Children with Thalassemia and their Caregivers in India. Available from: URL: https://www.ncbi.nlm.nih.gov/pubmed/27924466.

2) A. Bazi, O. Sargazi-Aval, et al. J Pediatr Hematol Oncol. Health-related Quality of Life and Associated Factors Among Thalassemia Major Patients, Southeast of Iran, 2017 act;39(7):513-517. Available from: URL: https:// www. ncbi. nlm. nih. gov/ pubmed/ 28859037.

3) Caocci Giovanni , Efficace Fabio, et al. Health related quality of life in Middle Eastern children with beta-thalassemia. BMC Hematology journal, 22 June 2012. Available from: URL: https://bmchematol.biomedcentral.com/articles/10.1186/1471-2326-12-6:6.

4) Adriana Ismail, et al, Health related quality of life in Malaysian children with thalassemia, $2006 \mathrm{Jul}$ 2. Available from: URL: https:// www. ncbi. nlm. nih.gov/ pmc/ articles/PMC1538578/

5) Fatemeh Behdani, Psychological Aspects in Children and Adolescents With Major Thalassemia: A Case-Control Study, 2015 Jun 27, Available from: URL: https:// www. ncbi.nlm.nih.gov/pmc/articles/PMC4505986/ 